\title{
LAS CADERAS
}

\author{
José María Espinasa \\ Al César lo que es del César/ \\ y al fémur lo que es del fémur.
}

\author{
La sola palabra \\ lleva con ella \\ un ritmo implícito, \\ las de todos \\ como las de Elvis \\ se mueven siempre \\ aunque estén en reposo.
}

Véase si no su diccionario:

fémur, el hueso más grande del ser humano, con un eco de la prehistoria, de la pertenencia a otra escala de medida. Pero ese es apenas un índice de acusadora verticalidad antes de desembocar en la cadera.

Más que doler se quiebra, se quiebra en todos los sentidos, algunos graves, otros juguetones. Sin carne parece un ser orejón, y sus articulaciones crujen con el tiempo.

El fémur tiene, por cierto, cabeza y se suele gastar si se la usa indebidamente. Hoy, dicen, se opera, pero no es igual. Centro del cuerpo: 
a partir de allí se articula el caminar sobre pies que son el reflejo fascinante de unas alas invertidas, de unas alas que escogieron la tierra como cielo.

No se les reconoce su condición de esqueleto, tal vez porque más allá del plural no son pares ni, desprendidas, se individualizan del cuerpo, no tienen un pasado criminal (como la quijada) ni parpadean como las rodillas o los codos.

Lo calcáreo en la cadera se vuelve suave al tacto, se pierde bajo diferentes distancias, es un hueso que sólo pertenece a la huesa y aplaude con los pies lo que reprueba con las manos.

Frente al fémur, no el húmero, tan Vallejo, si no el cóccix, tan sonoro. Es un hueso que suena a fósil aún vivo y que ya cadáver se escribe con $\mathrm{x}$. Hasta dónde los flexibles ligamentos permiten acentuar palabras esdrújulas como la ley exige. Hasta dónde se tuerce la cadera y toma la vuelta de una esquina en ángulo suicida y queda visco de los pies y la nariz. Habría escrito visco con b de haberte visto a los ojos. 